\title{
On Loving Neighbours and Others: Effective Altruism and Christian Ethics in a Relational Models Theory Perspective
}

\begin{abstract}
Christian traditions have tended to focus on "neighbours" as the primary target of altruistic actions, while the starting point of effective altruist reasoning is that spatial or personal nearness and distance should not count as a criterion of moral duty. This paper builds on insights from Relational Models Theory, a metatheory of human relationships that distinguishes four major models of human interactional patterns and concomitant moral ideologies. These four "relational models" shape a wide range of cultural features such as modes of decision making and types of group consciousness, influence value preferences, and thus affect inclinations to peculiar forms of ethical argument. Hence Relational Models Theory sheds light on both effective altruist arguments and characteristically Christian moral sentiments and shows the limitations and potential of both. Christian ethics as well as effective altruism are demanding and attractive, can learn from each other and can steer philanthropy to appropriate levels of reflection and action.
\end{abstract}

\section{Altruism, Relationships, and Relational Models Theory}

In his captivating book Factfulness (published in 2018), ${ }^{1}$ the late Hans Rosling, a Swedish professor of international health, mentions an incident during his work in Mozambique as a medical doctor in the early 1980s. At the time, he was the only university-trained physician serving 300,000 people, and one day a European colleague who visited him was "very upset" about the oral dehydration treatment that Rosling had prescribed to an infant. The colleague insisted that the baby be given a more effective intravenous drip ${ }^{2}$ - which, however, would take the doctor more than half an hour's additional work - and argued, "You must do everything you can for every patient who presents at the hospital." Rosling retorted, "It is unethical to spend all my time and resources trying to save those who come here. I can save more children if I improve the services outside the hospital. I am responsible for all the child deaths in this district: the deaths I do not see just as much as the deaths in front of my eyes." 3 While the colleague remained unconvinced, Rosling concludes at the end of the story,

1 Rosling et al, Factfulness.

2 Ibid., 125.

3 Ibid., 126. 
"Paying too much attention to the individual visible victim [...] can lead us to spend all our resources on a fraction of the problem, and therefore save many fewer lives. [...] It is hard for people to talk about resources when it comes to saving lives, or prolonging or improving them. Doing so is often taken for heartlessness. Yet so long as resources are not infinite - and they never are - it is the most compassionate thing to do." ${ }^{4}$

Effective altruism (EA) did not exist as a concept in the 1980s, and Rosling's book - which suggests that the world is in a much better state than most people think - does not contain any reference to the EA movement, its protagonists, and the major elements of its discourse. However, because of his passionate evidence orientation, I am sure that EA thought leaders would recognise him as a close ally. But what about Christians? Does his reasoning resonate with their maxim that one ought to love neighbours? Was the fellow doctor really wrong - or did he actually demonstrate the kind of compassion that is necessary in relating to those who live around you?

On a more general level, this question addresses the issue of the role of relationships in ethics. While this issue is complex and actually conflates topics such as spatial, conjugal, family, friendship, peer group, "ethnic," and "national" association, it is clear that interpersonal relationships are key in most areas of moral reasoning. Yet precisely what importance they should have - or, rather, which types of relationships determine one's duty or define appropriate actions - is contested, and evidently, perspectives on this matter are strongly shaped by cultural habits and assumptions.

This paper utilises a metatheory from the social sciences, i.e. a theory that synthesises well-known models from fields such as cultural anthropology, psychology, and economics, to shed light on both EA arguments and characteristically Christian moral sentiments. This metatheory, Relational Models Theory (RMT), developed in the late 1980s by psychological anthropologist Alan P. Fiske, builds on several earlier social theories ${ }^{5}$ as well as extensive field research in West Africa. ${ }^{6}$ The theory starts from the observation that humans are fundamentally social and suggests that sociality

4 Ibid., 127-128.

5 Fiske, "The Four Elementary Forms of Sociality," 710-712, 717-723; and Fiske, "Four Modes of Constituting Relationships," 16-21. Fiske explains that the theory emerged from a synthesis of Jean Piaget's developmental psychology, Max Weber's sociology of authority, Karl Polanyi's economic anthropology, and Paul Ricoeur's symbols theory.

6 The results of his two-year fieldwork are found in Fiske, "Relativity within Moose ('Mossi') Culture, ”180-204, and his book Fiske, Structures of Social Life, 231-368 (part IV). 
expresses itself in exactly four "elementary forms", i.e. unconscious but universally operational models, which exist in all cultures brought forth by human beings. ${ }^{7}$

According to RMT, every human relationship and, therefore, all contact and interface between individuals and groups is structured according to at least one of these four. Each of them follows a different principle and is experienced and re-enacted successively by children and youth as they grow up: Communal Sharing (CS) arises from the close psycho-physical bonds of those who relate, Authority Ranking (AR) is marked by a spatiotemporal hierarchy, Equality Matching (EM) consists of egalitarian procedures, and Market Pricing (MP) is lived on the basis of somewhat more abstract notions of proportionality viz. ratios. ${ }^{8}$ One crucial and convincing element in the theory is that the four models are not mere abstractions but describe modes of human interaction which are unavoidably learnt and serve as concrete action orientation in the first ten to twelve years of life.

RMT was scrutinised and validated in many ways in the $1990 s^{9}$ and has since been applied to a host of different research fields and academic disciplines. ${ }^{10}$ Today this theory can be regarded as a firmly established metatheory of the social sciences that is fertile in terms of generating research programmes. In the realms of theology and philosophy, RMT has made but

7 In a later study, Fiske defines the models from the perspective of "how people constitute social relationships": Fiske, "Four Modes of Constituting Relationships," 61-146.

8 The absence of any relationship (which includes rejection of other humans as humans or indifference about them) is called the "null relationship" in this theory; it is important to distinguish this non-relationship from hierarchical and contractual relationships, even when they are experienced as negative by persons involved.

9 See Haslam, "Research on the Relational Models," 28-33. Seven published studies examined and confirmed RMT with regard to the questions whether (1) there are only four forms of sociality, (2) if Fiske's characterization of these four is sound, and (3) whether the four models are categories and not dimensional continua.

10 For instance: personality dimensions, social errors, personality disorders, ethnography, studies of trust, values research, organizational behaviour, relationships between business companies, and political orientation. See, e.g., Caralis and Haslam, "Relational Tendencies," 397-402; Houde et al., "The Four Faces of Trust," 287-306; Biber et al, "Personal Values and Relational Models," 628; Earley, Face, Harmony, and Social Structure, 133136; Sheppard and Tuchinsky, "Interfirm Relationships: A Grammar of Pairs," 331-373; Simpson and Laham, "Different Relational Models," 204-217. For further fields and a discussion of these findings, see Haslam, "Research on the Relational Models," 34-51. 
little impact so far, ${ }^{11}$ but it is extremely promising with regard to ethics in several ways, for each of the four models suggests a different moral logic. I also propose that Relational Models Theory can illuminate the key ideas of EA and of New Testament ethics from a social science point of view, and can therefore help us compare, contrast, and possibly reconcile some elements of EA and Christian approaches to moral reasoning.

The four relational models shape a wide range of cultural features such as modes of decision making and types of group consciousness (see Table 1); they also correlate to typical values, and thus directly affect inclinations to peculiar forms of ethical argument. While Fiske devotes some reflection to the links that RMT has with moral reasoning, ${ }^{12}$ he does not engage with ethical theory as such and merely mentions in passing that "each type of social relationship depends on different virtues." 13 It is relevant that Fiske and one of his fellow researchers did develop a novel theory of violence based on the relational models ${ }^{14}$ and made a contribution to the field of moral psychology. ${ }^{15}$ However, a fuller exploration of the relational models with regard to theological or philosophical ethics is yet to be undertaken.

11 I used RMT in attempting to understand ecumenism - to develop a comprehensive theory of interchurch relations; see Höschele, "Interchurch Relations in Seventh-day Adventist History." So far I am not aware of other applications in the realm of theology. For reflections in the field of philosophy, see footnote 19.

12 Fiske, Structures of Social Life, 115-124 (the section "Morality, Legitimation, Law, and Ideology" of chapter 6, "Judgments").

13 Ibid., 123. He mentions Rawls, however, in the context of EM morality (p. 118) as the standard, which is justified, however, with a CS argument, "that actual differences in individual endowments must be regarded as communal assets that belong to the collectivity as a whole" and a contractual framework (=MP) as "legitimation of the principle of justice that maximizes the welfare of those who are worst off" (p. 119).

14 Fiske and Rai, Virtuous Violence.

15 Fiske and Rai, "Moral Psychology is Relationship Regulation," 57-75, and Rai, "Moral Psychology is Relationship Regulation." 


\section{Table 1: "Manifestations and features of four elementary relational models" according to Fiske ${ }^{16}$}

\begin{tabular}{|c|c|c|c|c|}
\hline $\begin{array}{l}\text { Domains and } \\
\text { Features }\end{array}$ & $\begin{array}{l}\text { Communal } \\
\text { Sharing (CS) }\end{array}$ & $\begin{array}{l}\text { Authority } \\
\text { Ranking (AR) }\end{array}$ & $\begin{array}{l}\text { Equality } \\
\text { Matching (EM) }\end{array}$ & $\begin{array}{l}\text { Market Pricing } \\
\text { (MP) }\end{array}$ \\
\hline $\begin{array}{l}\text { Characteristic } \\
\text { mode of } \\
\text { marking rela- } \\
\text { tionships }\end{array}$ & $\begin{array}{l}\text { Enactive, kinaes- } \\
\text { thetic, sensori- } \\
\text { motor rituals, } \\
\text { especially com- } \\
\text { mensal meals, } \\
\text { communion, and } \\
\text { blood sacrifice. }\end{array}$ & $\begin{array}{l}\text { Spatiotemporal } \\
\text { ordered arrays } \\
\text { (e.g., who is in } \\
\text { front, who comes } \\
\text { first). Differences } \\
\text { in magnitude (size } \\
\text { of dwelling, per- } \\
\text { sonal space, plural } \\
\text { pronouns for } \\
\text { respect). }\end{array}$ & $\begin{array}{l}\text { Concrete opera- } \\
\text { tions involving } \\
\text { physical manipula- } \\
\text { tions of tokens or } \\
\text { persons so as to } \\
\text { balance, match, } \\
\text { synchronize, align, } \\
\text { or place them in } \\
\text { one-for-one corre- } \\
\text { spondence. }\end{array}$ & $\begin{array}{l}\text { Abstract symbolic } \\
\text { representation } \\
\text { (especially propo- } \\
\text { sitional language } \\
\text { and arithmetic). }\end{array}$ \\
\hline $\begin{array}{l}\text { Constitution of } \\
\text { groups }\end{array}$ & $\begin{array}{l}\text { Sense of unity, sol- } \\
\text { idarity, shared sub- } \\
\text { stance (e.g., } \\
\text { "blood," kinship). } \\
\text { One-for-all, all- } \\
\text { for-one. Gemein- } \\
\text { schaft, mechanical } \\
\text { solidarity, primary } \\
\text { group. }\end{array}$ & $\begin{array}{l}\text { Followers of a } \\
\text { charismatic or } \\
\text { other leader. Hier- } \\
\text { archical organiza- } \\
\text { tion (e.g., mili- } \\
\text { tary). }\end{array}$ & $\begin{array}{l}\text { Equal-status peer } \\
\text { groups. For } \\
\text { example, car pool, } \\
\text { cooperative, and } \\
\text { rotating credit } \\
\text { association. }\end{array}$ & $\begin{array}{l}\text { Corporations, } \\
\text { labour unions, } \\
\text { stock markets and } \\
\text { commodity asso- } \\
\text { ciations. } \\
\text { Gesellschaft, } \\
\text { organic solidarity. } \\
\text { Also, bureaucracy } \\
\text { with regulations } \\
\text { oriented to prag- } \\
\text { matic efficiency: } \\
\text { rational-legal orga- } \\
\text { nization. }\end{array}$ \\
\hline $\begin{array}{l}\text { Decision } \\
\text { making }\end{array}$ & $\begin{array}{l}\text { Group seeks con- } \\
\text { sensus, unity, the } \\
\text { sense of the group } \\
\text { (e.g., Quaker } \\
\text { meeting, Japanese } \\
\text { groups). }\end{array}$ & $\begin{array}{l}\text { By authoritative } \\
\text { fiat or decree. Will } \\
\text { of the leader is } \\
\text { transmitted } \\
\text { through the chain } \\
\text { of command. Sub- } \\
\text { ordinates obey } \\
\text { orders. }\end{array}$ & $\begin{array}{l}\text { One-person, one- } \\
\text { vote election. } \\
\text { Everyone has } \\
\text { equal say. Also } \\
\text { rotating offices or } \\
\text { lottery. }\end{array}$ & $\begin{array}{l}\text { Market decides, } \\
\text { governed by } \\
\text { supply and } \\
\text { demand or } \\
\text { expected utilities. } \\
\text { Also rational cost } \\
\text { and benefit ana- } \\
\text { lysis. }\end{array}$ \\
\hline
\end{tabular}

16 Shortened and slightly adapted from Fiske, "The Four Elementary Forms of Sociality," 694-696. The original 3-page table lists further details which are less relevant for this study - reciprocal exchange, distributive justice, work, the significance of (material) things, orientations to land, significance of time, social influence, social identity and self, motivation, interpretation of misfortune, (violent) aggression and conflict, related natural selection mechanisms, and approximate age when children first externalize the model. 


\begin{tabular}{|c|c|c|c|c|}
\hline $\begin{array}{l}\text { Domains and } \\
\text { Features }\end{array}$ & $\begin{array}{l}\text { Communal } \\
\text { Sharing (CS) }\end{array}$ & $\begin{array}{l}\text { Authority } \\
\text { Ranking (AR) }\end{array}$ & $\begin{array}{l}\text { Equality } \\
\text { Matching (EM) }\end{array}$ & $\begin{array}{l}\text { Market Pricing } \\
\text { (MP) }\end{array}$ \\
\hline Contribution & $\begin{array}{l}\text { Everyone gives } \\
\text { what they have, } \\
\text { without keeping } \\
\text { track of what indi- } \\
\text { viduals contribute. } \\
\text { "What's mine is } \\
\text { yours." }\end{array}$ & $\begin{array}{l}\text { Noblesse oblige: } \\
\text { superiors give } \\
\text { beneficently, } \\
\text { demonstrating } \\
\text { their nobility and } \\
\text { largesse. Subordi- } \\
\text { nate recipients of } \\
\text { gifts are honoured. }\end{array}$ & $\begin{array}{l}\text { Each contributor } \\
\text { matches each } \\
\text { other's donations } \\
\text { equally. }\end{array}$ & $\begin{array}{l}\text { People assessed } \\
\text { according to a } \\
\text { fixed ratio or per- } \\
\text { centage (e.g., } \\
\text { tithing, sales, or } \\
\text { real estate taxes). }\end{array}$ \\
\hline $\begin{array}{l}\text { Moral judg- } \\
\text { ment and ide- } \\
\text { ology }\end{array}$ & $\begin{array}{l}\text { Caring, kindness, } \\
\text { altruism, selfless } \\
\text { generosity. Pro- } \\
\text { tecting intimate } \\
\text { personal relation- } \\
\text { ships. Traditional } \\
\text { legitimation in } \\
\text { terms of inherent, } \\
\text { essential nature or } \\
\text { karma of group. }\end{array}$ & $\begin{array}{l}\text { What supreme } \\
\text { being commands } \\
\text { is right. Obedi- } \\
\text { ence to will of } \\
\text { superiors. Het- } \\
\text { eronomy, charis- } \\
\text { matic legitima- } \\
\text { tion. }\end{array}$ & $\begin{array}{l}\text { Fairness as strict } \\
\text { equality, equal } \\
\text { treatment, and } \\
\text { balanced reci- } \\
\text { procity. }\end{array}$ & $\begin{array}{l}\text { Abstract, uni- } \\
\text { versal, rational } \\
\text { principles based } \\
\text { on the utilitarian } \\
\text { criterion of the } \\
\text { greatest good for } \\
\text { the greatest } \\
\text { number (ratio } \\
\text { metric for } \\
\text { assessing all costs } \\
\text { and benefits). } \\
\text { Rational-legal legit- } \\
\text { imation. }\end{array}$ \\
\hline $\begin{array}{l}\text { Features that } \\
\text { the cultural } \\
\text { implementa- } \\
\text { tion rules must } \\
\text { specify }\end{array}$ & $\begin{array}{l}\text { Who is "us" and } \\
\text { who is "other," } \\
\text { including how } \\
\text { people acquire and } \\
\text { lose corporate } \\
\text { membership. } \\
\text { What is shared. } \\
\text { What kinds of } \\
\text { restraint people } \\
\text { must exercise and } \\
\text { what excuses them } \\
\text { from giving. }\end{array}$ & $\begin{array}{l}\text { What are the cri- } \\
\text { teria for rank. } \\
\text { What dimensions } \\
\text { mark precedence. } \\
\text { In what domains } \\
\text { may authority be } \\
\text { exercised. }\end{array}$ & $\begin{array}{l}\text { Who and what } \\
\text { counts as equal. } \\
\text { What procedures } \\
\text { people use for } \\
\text { matching and bal- } \\
\text { ancing. What are } \\
\text { the appropriate } \\
\text { delays before } \\
\text { reciprocating. }\end{array}$ & $\begin{array}{l}\text { What entities may } \\
\text { be bought and } \\
\text { sold (e.g., sex? } \\
\text { drugs? votes? } \\
\text { people?). What are } \\
\text { the ratios of } \\
\text { exchange? What } \\
\text { counts as a cost or } \\
\text { a benefit. }\end{array}$ \\
\hline $\begin{array}{l}\text { Corresponding } \\
\text { scale type }\end{array}$ & $\begin{array}{l}\text { Categorical or } \\
\text { nominal. }\end{array}$ & Ordinal. & Interval. & Ratio. \\
\hline
\end{tabular}

For the purpose of this paper, it must suffice to point out that the relational models are not primarily what we call ideas, values, or motivations. They do engender all of these, for the four relational models are, first of all, learnt modes of human interaction, i.e. results of emulation, with concomitant values and motivations being inherent in wholistic relational settings, and ideas being derived from them in a secondary manner. Yet RMT as a general theory, located between social anthropology and psychology, evidently illuminates what Fiske calls human "moral commitments": it describes the normative force of culture upon those who belong to particular groups by 
way of explaining everyday interpersonal behaviour and the expectations created by such behaviour.

The defining elements of each relational model are distinct types of actions: "consubstantial assimilation" for CS (as found in sharing food, body contact, sex, dance, nursing, or shared pain); "social physics" in AR (size, position in space, visible hierarchy); "concrete operations" (EM) of taking turns, reciprocating, balloting, or working in unison alongside; and the use of symbolic signs (MP) as found in writing, propositional language (e.g. contracts), exchange with money involved. ${ }^{17}$ These actions imply, of course, value preferences or a sense of what is "right" or "appropriate." Thus, CS lends itself to values such as love and benevolence, AR to values derived from an authority orientation, EM to equality, and MP to individual freedom and individual responsibility. These values can also be translated into more abstract ideas, and go along with concomitant motivations for individuals to act in specific ways: to conform to consensus (CS), to obey to a supreme being, ruler, or norm (AR), to share the same amount of burden or privilege as everyone else (EM), or to decide according to a cost-benefit calculus (MP). ${ }^{18}$ Thus, although RMT theorists insist that relationships and their performance are primary, concepts derived from them are clearly relevant to discussions of morality.

The little extant reasoning so far on the RMT-ethics nexus is neatly summarised by John Bolender, the primary philosophical interpreter of Fiske's theory so far. It is quoted here at length because Bolender presents the basic concepts of what is applicable to the discussion below: ${ }^{19}$

"Each elementary model crucially enters into certain moral values. [1] An ethic of service to one's group is a form of Communal Sharing [CS]. It is an altruistic ethic in some sense, but bear in mind that all members of the group share a common identity. So, strictly speaking, it is not true altruism. [2] Authority Ranking [AR] informs an ethic of obedience to authority including respect, honor, and loyalty. Any questions of value remaining to be clarified are settled by the authority; subordinates are expected to follow the values thus dictated. [3] Fairness and even distribution are informed by Equality Matching [EM]. John Rawls' veil of ignorance exemplifies

17 Fiske, "Four Modes of Constituting Relationships," 64.

18 Thus, one can even differentiate typical modes of arriving at moral prescriptions. While AR relationships imply an unbending must, an MP relationship frames responsibilities as something a person has committed to; EM implies that someone will insist on justice in a specific sense, and members of CS groups will argue that one naturally does such and such in our group. Thus, what morality actually "is" or how it "functions" differs dramatically among the four relational frameworks.

19 See Bolender, The Self-Organizing Social Mind; and Bolender, Digital Social Mind. 
Equality Matching; a perspective in which one does not know which role one will play guarantees that one aim for equality. [...] [4] Market Pricing [MP] informs libertarian values of freely entering into contracts and taking risks with the aim of increasing one's own utility or the utility of one's group. But this also includes suffering the losses when one's calculations prove incorrect. Utilitarianism is a somewhat counterintuitive attempt to extend this sort of morality to all sentient life, but is still recognizable as Market Pricing.

It would be too simple, however, to say that there are only four sorts of values in RMT. In fact, combinations of models yield complex models, resulting in a potential infinity of complex values. [...] This great variety of values leads to value conflicts most noticeably across cultures." 20

While Bolender's reference to both libertarian values and utilitarianism as relating to Market Pricing may seem surprising, it demonstrates that building blocks of different moral theories can be derived from the same relational model, even if the ultimate emphasis in one theory can differ drastically from another. Moreover, Bolender's observation that combinations of relational models are characteristic of complex moral reasoning is crucial in evaluating approaches to ethics. The history of ethics may have brought forth a few attempts at constructing systems that essentially reflect a single-issue approach (e.g. with "love" at the basis of certain versions of situation ethics, coming close to Communal Sharing, or divine command theory, an example of Authority Ranking). In most cases, however, theories of ethics emphasise two or more major values, thus merging or joining associated relational models in specific manners. Virtue ethics, for instance, has both a CS and an EM tendency, thus combining major in-group values with what is thought of as being ideals valid for all humans. Many deontological approaches to ethics have an authority (AR) bent, ${ }^{21}$ but some add justice ingredients (corresponding to an EM orientation) while others include contractual reasoning (corresponding to what RMT calls the

20 Bolender, "Relational Models Theory." Numbers and abbreviations in brackets added by S.H.

21 A casuistic religious approach to ethics, in which the properly appointed authority regulates all questions of moral impact, might be the most distinctively AR system of ethics. 
Market Pricing (MP) relational model). ${ }^{22}$ All the defining factors that moral reasoning commonly appeals to ${ }^{23}$ are linked to one or more than one of these relational models in specific ways. ${ }^{24}$

\section{Effective Altruism in a Relational Models Theory Perspective}

So how does EA relate to the four relational models and their concomitant moral emphases?25 According to MacAskill, the EA movement "takes a scientific approach to doing good"; its ethos "consists of the honest and impartial attempt to work out what's best for the world, and a commitment to do what's best, whatever that turns out to be."26 This definition (like others, which are generally quite similar) ${ }^{27}$ contains pointers toward three of the relational models relevant for EA reasoning:

22 Popular morality often exhibits various mixtures - e.g. of Authority Ranking and Communal Sharing orientations: what is deemed "moral" is what is expected by the immediate in-group and its leading personalities and traditions, with little reference to more general values (such as justice viz. EM). But depending on the setting, it might also emphasize EM principles (e.g. in a project team) or mix them with space for individual agreements (MP) to make everyday life run more smoothly. Thanks to Stefan Riedener for pointing me to the need of clarification on this point.

23 Such as (a) the good and (b) evil, (c) nature, (d) law, (e) norms and rules, (f) duty, (g) values, (h) freedom and (i) responsibility, (j) means and (k) consequences, (l) conscience, $(\mathrm{m})$ vice and $(\mathrm{n})$ virtue, (o) community, $(\mathrm{p})$ the nature of persons with their will, affects, and rationality, and (in religious contexts) (q) sin; I have listed these elements roughly according to chapters in Mühling, Systematische Theologie, 19.

24 In the context of this paper, time and space do not suffice to further develop these links and this theme in general. Yet exploring the bearing of Relational Models Theory upon ethical theory would certainly yield a major study of its own.

25 This paper was originally presented in summer 2019; thus, literature appearing around this time or later, including The Precicipe by Toby Ord and Effective Altruism: Philosophical Issues by Hilary Greaves and Theron Pummer (eds.), has not been consulted for the following discussion. Since the most basic structure of EA moral reasoning has not changed, this does not alter my general argument.

26 MacAskill, Doing Good Better, 15.

27 " 1 . Being open to all the possible ways to do good and pursuing the path with the biggest positive impact; 2 . Using evidence to figure out how to do the most good; and 3. Choosing to make altruism a significant part of one's life." Singer and MacAskill, "Introduction", vi. Singer also defines that EA is "based on a very simple idea: we should do the most good we can." Most Good, vii. MacAskill formulates that EA aims at making "the world as good a place as it can possibly be." MacAskill, "What is Effective Altruism?," 3. 
(a) The Market Pricing relationship (which might have better been called "market exchange" relationship) with its rational ("honest and impartial") cost-benefit analysis, evidence-based ("scientific") utilitarian ethos and trade logic forms the backbone of the entire system. A maximum of happiness viz. reduction of suffering - to be measured as thoroughly as possible ${ }^{28}$ - can be, and should be, "bought" by "investing" means at one's disposal at the lowest price possible so that resources can be used to their maximum.

(b) The Communal Sharing relational model is of no lesser importance for EA theorists. Their uniform insistence on the need of focus upon "the most good" and the very term "altruism," which implies attention to the welfare of others, mirrors the "flesh" of EA morality: improving the overall well-being of individuals, and doing so without asking about the personal cost involved at the very outset.

EA - as its two constituent terms imply - is, therefore, essentially a hybrid: CS values promoted with an MP mind-set. The result of this bond is the creation of an ethos that expands Communal Sharing principles of caring, mutual responsibility, and free access to resources to a realm far beyond their "natural" habitat (i.e. kin, close friends, and imagined communities of common descent). The genius of EA is, therefore, to claim universal validity for moral standards that typically apply only to small-scale groups. At the same time, EA tames Market Pricing, for its libertarian and contract-based logic is limited by every sentient being's suffering and potential but not-yet-fulfilled happiness. Thus, MP norms, which are taken for granted, are essentially at the service of Communal Sharing values, which are viewed as being in need of realisation. This peculiar CS-MP hybrid implies, at the same time...

(c) the absence, even rejection of moral authorities. Traditional norms, religious writings - even wise words of leading persons of the EA movement itself such as Singer and MacAskill - do not play a normative role. The Authority Ranking principle is ignored; what is good, "whatever that turns out to be," is to be found on the basis of utilitarian calculus, and

28 There is no need here to present and discuss MacAskill's use (Doing Good Better, 3945) of the QALY as a measurement, but in all the extant EA literature, measuring and comparing benefits on scales and in various units (currency, life years, etc.) is an important aspect of argumentation. See (in addition to the books mentioned above) Todd, 80,000 Hours; and the predecessor book to the EA movement, Singer, Life You Can Save. See also Cooney, Be Great at Doing Good. While Cooney does not self-identify as an effective altruist in his book and does not mention EA, his arguments are very similar, and William MacAskill recommends the book on the "praise" pages that precede the title page. 
the "scientific" component implies - at least for the founders of EA - a decidedly secular, non-theistic rationality. EA may best be understood as being thoroughly opposed to systems that derive norms from traditional morality.

(d) And what about Equality Matching? EM is the kind of "fairness" relationship which children learn, e.g. by distributing or receiving exactly the same number of candy. Effective altruists do not seem to be overly burdened with notions of impartiality expressed in equal distribution as long as this does not directly touch on the amount of suffering in sentient beings. While they emphasise that everyone's suffering counts equally (a typical EM-related argument), ${ }^{29}$ thus directly challenging the archetypal Communal Sharing limitation to blood bonds, the Western preoccupation with democratic values such as "justice, freedom, equality, and knowledge" 30 is mitigated by declaring these to be ancillary to the goal of attaining more happiness and less suffering. ${ }^{31}$ Thus the strictly egalitarian Equality Matching morality is neither viewed as absolute nor as primary; all in all, the spokespersons of EA appear to be positive in theory about this orientation but remain somewhat indifferent because of their exceptionally strong insistence upon CS values, even though the practical outcome of their activities will mostly lead to more justice as well.

\section{New Testament Ethics and the Relational Models}

Summarising the main aspects of Christian ethics in a few paragraphs is much more challenging than doing so for EA: the EA movement has produced fewer than ten major books so far while discussions on Christian ethics may fill entire libraries. Nevertheless, the grid provided by Relational Models Theory can help identify the main emphases of New Testament writers $^{32}$ in a way that these can be contrasted with EA emphases. Since biblical emphases have remained foundational for later Christian theological-ethical reasoning, and as this paper cannot possibly do justice to the

29 Singer asks, "Does everyone's suffering count equally?," and answers that the EA movement affirms this with regard to human suffering; see Singer, Most Good, 7.

30 Ibid., 146. "Justice" and "equality" are the typical EM values; democratic values at large are a blend of EM and MP values (the latter implying a rational, cost-benefit perspective).

31 Singer, Most Good, 7.

32 For a helpful and differentiated introduction to the complexity in the study of New Testament ethics viz. morality, see Cosgrove, "New Testament Ethics," 549-552. 
variety of approaches to moral theology, the following discussion will be limited to New Testament ethics. ${ }^{33}$

While the feasibility of comprehensively reconstructing an ethic of the historical Jesus is debated, it is clear that its major emphases resulted from his proclamation of God's near kingdom: (1) consistent agape love of neighbour, even of enemies; (2) love of God, to be demonstrated in radically following divine principles (coupled with a somewhat critical view of traditional norms); and - to some extent - (3) justice springing from righteousness as a consequence of God's forgiveness. ${ }^{34}$ The writers of the synoptic gospels accentuate (4) discipleship, (5) a critical view of striving for material wealth arising from a concern for the poor and their welfare, and (6) some degree of a normative view of the Christian life ("parenesis"), albeit without any legalistic outlook. ${ }^{35}$ The epistles, finally, stress (7) the origin of all good works in the grace of God (especially Paul), (8) virtues to be sought (and corresponding vices to be avoided), and (9) the responsibility of the believer in the context of the family, the local congregation, the network of Christian churches, and the world at large. ${ }^{36}$

This overall picture of New Testament ethics points to three of the RMT models as being pertinent to various degrees and in different ways.

(a) Communal Sharing is evidently the key to understanding the Christian ethos; it is reflected in agape love (1), concern for the poor (5), the importance of forgiveness (3) and grace (7), and the responsibility of believers for others (9). Both the latter and Jesus' extension of love to enemies - as well as his nearly boundless re-definition of "neighbours" (by including the despised Samaritans) ${ }^{37}$ point to what may be called a modified

33 The Old Testament does, of course, play an important role as a background to New Testament ethics, and its ethical content has been used in divergent ways (and has, often, been largely ignored) in Christian ethics. Suffice it to say that the Decalogue is the only major OT text with a moral relevance that has been of prominence in most confessional traditions.

34 For references and a summarizing account see McFee, "Values, Value Judgments," 803805; for a comprehensive discussion see Schrage, Ethik des Neuen Testaments, 20-99 (on Jesus) and 117-133 (treating Matthew and Luke with discussions on righteousness, justice, and the relationship between different groups of society).

35 Schrage, Ethik des Neuen Testaments, 113-133.

36 Ibid., 134-265; and (a very succinct summary) Merk, "Ethics - NT Ethics," 147-148.

37 See the parable of the Good Samaritan (Luke 10:25-37). The antagonism between the Jews of Jesus' time and the Samaritans was due to religious quarrels that included the criticism of Samaritan "syncretism" but actually revolved around a number of intraIsraelite theological disputes (such as the status of various writings as Holy Scripture and the proper place of temple worship). 
CS model: it is fundamentally open and thus categorically transcends the emblematic kin-related Communal Sharing logic.

(b) These CS values are promoted, and rest upon, the basis of a system of belief that combines the Creator God with the conviction that he acts powerfully in history and in the life of believers. He is, therefore, to be loved by living according to his will, viz. Christ's exemplification of the same $(2,4)$. In other words, the religious message proclaimed by the early Christians, and the moral system they lived within, (6) was based upon the highest authority that humans could imagine. With such an Authority Ranking relationship to the one and only God, the ethical teachings thus promoted gained the sanction that was needed in the economy of competing systems. At the same time, the lack of a legalistic bent in the New Testament writings, and the emphasis on following Jesus as an individual (and related notions of conscience) as opposed to traditional authorities (2, 6) imply a moderation of the AR impact on morality. ${ }^{38}$

(c) Except for the potent agape concept, early Christian principles of the moral life did not necessarily differ much from those in the Hellenistic environment. Especially in the later New Testament writings, lists of virtues to be sought by everyone alike (8) and the so-called Haustafeln (domestic codes) ${ }^{39}$ closely resemble contemporary texts of the same genre. Nevertheless, New Testament virtue ethics also extols notions of justice (3) inherited from the Old Testament zedaqâ concept and translating into an incipient egalitarianism. Thus, an Equality Matching-related ethical perspective characterises at least part of the Christian ethos; while it was not fully developed in the framework of the hierarchical societies in which early Christianity operated, some degree of egalitarian treatment was to be extended to women, slaves, and foreigners as well (9).

38 Later developments in the Christian Church such as the establishment of canon law and the emergence of traditionalist movements and groups with a sectarian bent opened the door for casuistic and legalistic approaches, which drew its legitimacy from a predominant authority orientation.

39 Mainly Ephesians 5:22-6:5 and Colossians 3:18-4:1; cf. also 1 Peter 2:13-3:7 and sections from the pastoral letters such as 1 Timothy $2: 8-15,5: 1-8$, Titus 2:1-10. 
(d) The fact that the Market Pricing relational model is almost absent in New Testament texts of ethical importance ${ }^{40}$ warrants considerably more discussion than can be included in this paper. This absence may be interpreted in different ways, ranging from (1) active rejection through (2) cautious counsel against "calculating" approaches, (3) a neutral stance, or (4) a valuable option little known in NT times to (5) a type of assessing moral issues that is indirectly supported. On each of these options, only a short sketch will be presented here.

(1) Active rejection of MP approaches? Agape does not calculate; it represents love without thinking of the consequences (a "pure CS" attitude); therefore, the New Testament speaks against MP; it actually prohibits the weighing of good deeds, which implies that Christians must reject or even fight this approach.

(2) The New Testament discourages a cold "calculus" approach and thus indirectly counsels against asking for "effectiveness" in comparing actions. While such an orientation may be tolerable in some instances (e.g. when governments or businesses make decisions for their realms), it should not characterise Christian ethics.

(3) In the absence of the public discourses that develop with the help of modern media, MP approaches to morality were not imaginable at the time. The idea of a maximisation of effects was thinkable in business, and there it was deemed problematic. ${ }^{41}$ Thus cost-benefit analysis in the realm of ethics was unknown but not "forbidden."

(4) A "calculatory" approach to ethics was theoretically imaginable, but not common in the environment. Science, measurements, etc. did not appeal to people's moral "common sense" at the time; at the same time, it would have been supported had the New Testament been written in a society where such an orientation played a stronger role. Thus, an MP-type morality may have been, in NT times, a blind spot but an acceptable option depending on the issue - especially regarding matters which were not explicitly addressed in the New Testament.

40 One possible example is the parable of the Shrewd Manager in Luke 16:1-13. Since it is fraught with various exegetical challenges and appears to belong to the group of parables in which Jesus uses paradoxical or shocking examples to exemplify his key point (here, that "you cannot serve both God and Money", v. 13), it would be far-fetched to categorize the story with Market Pricing.

41 See the woes to the rich in James 5:1-6 and discussions of cultural perspectives on wealth in New Testament times in Malina, New Testament World, chapter 3. 
(5) New Testament narratives, instructions, and parenetical sections are not to be construed to imply a set of "Christian laws." Rather, they illustrate a reasonable response to challenges of the time based on the gospel and on what was considered appropriate in a society that was very different from today's. Contextually applied reasonableness is to be supported even today; effectiveness (i.e., an MP orientation) is, in today's world, a major criterion in ethical reflections on impact, particularly with regard to large-scale issues.

Whatever the reason for an absence of distinctly MP-patterned approaches to morality in the New Testament, on the basis of the emphases outlined above (CS, AR, and some EM) it is clear Christians have traditionally tended to ignore cost-benefit calculations in their thinking on morality.

All in all, New Testament ethics consists in a radical support for Communal Sharing values and practices to be extended both to believers and to humans in general. The ideological basis for this ethos, divine authority, was the strongest validation possible at the time; the backbone of the Christian message and praxis of agape love, therefore, was an Authority Ranking framework, which fit in well with the common hierarchical setup of society at the time. While Market Pricing patterns of moral argument were evidently missing, egalitarian (Equality Matching) elements did play a certain role in the burgeoning early Christian congregations, although unsurprisingly concepts of justice derived from today's strictly democratic perspective had not yet developed.

\section{On Loving Neighbours and Others}

EA and the New Testament foundations for Christian ethics largely agree on the key element that characterises moral actions: the kind of love that values the Other as much as the own person. ${ }^{42}$ While emphases differ, the overall perspective is remarkably close: altruistic action - the characteristic element of Communal Sharing or agape - is not only to be directed to one's family, friends, and those living in proximity, but to everyone. Jesus'

42 Probably Christians would go further in theory and promote selflessness even when this leads to a lack of resources. What the EA and Christian moral perspective agree upon is that there is a duty to the Other at least once one's own basic needs are fulfilled (cf. the biblical demand to love one's neighbour "as yourself"). 
widening of the "neighbour" idea 43 and the EA insistence upon regarding all humans as counting the same as potential recipients of support in the reduction of suffering ${ }^{44}$ imply the same altruistic universalism. In the following paragraphs, I will point to the key difference between EA and Christian ethics, mention two issues on which Christians would question EA assumptions, and suggest what Christians can learn from EA.

The major difference is certainly the rationale given, and the mode of application of this ethical core. Both New Testament Christianity and EA claim far-reaching validity; what differs is the figures of thought and associated relational model preference that are appealed to. The MP relationship, based on ratios of exchange and abstract logic, is prevalent in the public sphere of modern societies and appeals to those who derive their identity or ideology from science. EA, therefore, seems "logical," but is in actual fact clearly contextually embedded. This is true as well for New Testament reasoning, which appealed to the highest authority that could be imagined at the epoch - the one and only God. Thus, even this difference between EA and Christian ethics contains a similarity in one respect: authority has shifted from the divine to the empirical, "scientific" realm, but this shift reflects the respective public sentiment of the time.

Yet even the empirical realm, which EA proponents claim as their turf, is not entirely value-neutral; the question of whether suffering and happiness, which utilitarians focus on and typically believe to be measurable, need to be the anchor points of ethics is not a matter of science but of moral philosophy. Actually, the very point of suffering can illustrate the difference between EA and New Testament authors in a precise manner: the apostle Peter argues that suffering is at times positive, ${ }^{45}$ and other New Testament characters also support the idea that affliction is not something

43 The parable of the Good Samaritan widens the "neighbour" concept to one's traditionally hated neighbours viz. neighbouring "nations," and the Sermon on the Mount with its emphasis on love of the enemy (Matthew 5:43-48) essentially applies love of neighbour to all humans, including persecutors and colonial rulers: the passage that precedes the "love of enemy" section recounts a typical scene of Roman colonial power, in which a soldier forces a Jew to walk a mile with him (mostly to carry items) - whence the proverbial "walking of the second mile."

44 Christians traditionally disagree with widening this perspective to all sentient species, as Singer and many effective altruists do, even though eminent Christian ethicists now stress animal rights as well, and a few Christian minority traditions (such as my own Seventh-day Adventist tradition) include a strong emphasis on vegetarianism.

451 Peter 2:20-21 (with an imitatio Christi rationale); 3:13-17; 4:1; 4:12-19; cf. 5:1; see also Jesus' words in Matthew 5:10-11. 
to be avoided. ${ }^{46}$ This is due, to some extent, to the fact that Christianity originally sprang from an apocalyptic orientation, which focused on the soon-to-be established kingdom of God. Thus, the first Christians did not intend to make a major impact on society, and even when they did, Christian ethics was hardly ever construed as providing a foundation for living in a world of global opportunities. At the same time, this inherited "interim" perspective on Christian existence also implies that happiness is possible in spite of suffering.

Moreover, effective altruists may do well to listen to perspectives (which are common among Christians) that suggest that a focus on the maximisation of "impact" may at least sometimes be problematic. ${ }^{47}$ The EA focus on measuring may result in support of short-term success in some fields but it may simply not be possible to measure long-term results of the same interventions. Vigorous debates on the impact of "development" projects with some theorists even rejecting any outside intervention - demonstrate that the last word on what is good, better, and best has not been spoken yet. Christians have accumulated much experience with good intentions leading to negative outcome, especially when churches were in a much more powerful position due to the Christendom setup; it would be a pity for EA activists to repeat mistakes that can be avoided (which is, of course, also true for the paternalism associated with some Christian missionary and development interventions).

A crucial aspect which Christian ethicists - and Christians in general - can learn from EA is the movement of further widening the horizon far beyond one's immediate environment. As the development of Christian Social Ethics from the early 20th century onward has shown, a general compatibility of biblical moral thinking with the challenges of modernising societies exists. Thus, ethics based on the New Testament can also take up issues that arise from the opportunities and complexities of a globalised world - which, essentially, means stretching moral concern beyond the realms of immediacy (CS), rank (AR), and mutuality (EM) towards all those who are affected by particular human interventions (MP). The fact that "neighbours" in the 21 st century world are no longer only the visible or physical neighbours is, of course, a considerable increase of complexity

46 See, e.g., Acts 4:40-41 (the apostles rejoice for being "worthy" of suffering for Christ's sake) and Philippians 1:29.

47 For this entire discussion (and a somewhat misguided critique of the EA movement, which focuses almost exclusively on Peter Singer's utilitarian philosophical basis), see Wydick, Shrewd Samaritan, 91-101 (chapter 6). 
(which may at times challenge traditional Christian practices of diakonia). If Jesus were to re-tell the story of the Good Samaritan today, he would possibly use a more globalised narrative.

A second major insight that Christians can receive from EA theorists is a significantly increased effectiveness orientation. With their myriad institutions and organisations in social work, medical service, and education, Christian churches have been aware of the requirements of good management, cost-effectiveness, and the like, for a long time. Thus, Rosling's concern in the introduction is not foreign to Christian practitioners of aid, health, and teaching. However, because of the lack of effectiveness criteria in the world where Christianity arose and the resultant paucity of cost-benefit arguments in New Testament ethics, it would be easy to overlook the moral importance to Christian decision making in general and in particular in a world that is shaped by MP factors to a much larger degree.

A third important inspiration for Christians coming from EA is the focus on neglected issues. By calculating the relative neglectedness of problems (a typical MP approach), EA activists function in a way that systemically makes sense wherever attention is not sufficiently directed towards a problematic area within a larger whole. Christians tend to derive areas of activism from the Scriptures, tradition and areas where the emotions are touched; EA thinking can contribute to widening attention to other even more relevant fields.

Both the central ideas of EA and the core of Christian ethics are demanding and, at the same time, attractive moral philosophy. From an outsider's point of view, they may nevertheless seem trivial to some extent in theory: that you must (AR) help others (CS) who are in real need regardless of who they are (New Testament) and that it makes a difference how many (MP) needy people you help (effective altruism) are almost common-sense statements as long as they do not require much sacrifice. Yet both the Christian emphasis on and the EA version of altruism demand more than an attitude or a philosophical commitment: they are about action done from conviction and essentially regard all of humanity as one community (CS). Both teach that decisions should not be made for acting individuals to feel good (at least not primarily) but to actually make the world a better place. In this regard, committed effective altruists and Christians willing to live their faith in a tangible manner can learn much from each other, challenge each other on blind spots, and together steer philanthropy, charitable giving, and humanitarian service to appropriate levels of reflection and action. 


\section{References}

Biber, Pascal, Hupfeld, Jörg, and Meier, Laurenz L. "Personal Values and Relational Models." European Journal of Personality 22, no. 7 (2008): 609-628.

Bolender, John. The Self-Organizing Social Mind. Cambridge: MIT Press, 2010.

- Digital Social Mind. Exeter: Imprint Academic, 2011.

- "Relational Models Theory." In Internet Encyclopedia of Philosophy, n.d. Accessed 15 July 2019. https://www.iep.utm.edu/r-models.

Caralis, Dionyssios and Haslam, Nick. "Relational Tendencies Associated with Broad Personality Dimensions." Psychology and Psychotherapy: Theory, Research and Practice 77, no. 3 (2004): 397-402.

Cooney, Nick. How to Be Great at Doing Good: Why Results Are What Count and How Smart Charity Can Change the World. Hoboken: Wiley, 2015.

Cosgrove, Charles H. "New Testament Ethics." In Dictionary of Scripture and Ethics, ed. Joel B. Green. Grand Rapids: Baker Academic, 2011.

Earley, P. Christopher. Face, Harmony, and Social Structure: An Analysis of Organizational Behavior Across Cultures. New York: Oxford University Press, 1997.

Fiske, Alan P. "Relativity within Moose ('Mossi') Culture: Four Incommensurable Models for Social Relationships." Ethos 18, no. 2 (1990): 180204.

. Structures of Social Life: The Four Elementary Forms of Human Relations. New York: Free Press, 1991.

. "The Four Elementary Forms of Sociality: Framework for a Unified Theory of Social Relations." Psychological Review 99, no. 4 (1992): 689-723.

- "Four Modes of Constituting Relationships: Consubstantial Assimilation [CS]; Space, Magnitude, Time and Force [AR]; Concrete Procedures [EM]; Abstract Symbolism [MP]." In Relational Models Theory: A Contemporary Overview, ed. Nick Haslam, 61-146. Mahwah: Erlbaum, 2004.

- "Relational Models Theory 2.0." In Relational Models Theory: A Contemporary Overview, ed. Nick Haslam, 3-26. Mahwah: Erlbaum, 2004.

and Tage Shakti Rai. "Moral Psychology is Relationship Regulation: Moral Motives for Unity, Hierarchy, Equality, and Proportionality." Psychological Review 118, no. 1 (2011): 57-75. 
and Tage Shakti Rai. Virtuous Violence: Hurting and Killing to Create, Sustain, End, and Honor Social Relationships. Cambridge: Cambridge University Press, 2014.

Haslam, Nick. "Research on the Relational Models: An Overview." In Relational Models Theory: A Contemporary Overview, ed. Nick Haslam, 27-57. Mahwah: Erlbaum, 2004.

Höschele, Stefan. "Interchurch Relations in Seventh-day Adventist History: A Study in Ecumenics." Habilitation thesis, Charles University, Prague, 2017.

Houde, Leah D. et al. "The Four Faces of Trust: An Empirical Study of the Nature of Trust in Relational Forms." In Relational Models Theory: A Contemporary Overview, ed. Nick Haslam, 287-306. Mahwah: Erlbaum, 2004.

MacAskill, William. Doing Good Better: Effective Altruism and a Radical New Way to Make a Difference. London: Guardian, 2016. "What is Effective Altruism?" In The Effective Altruism Handbook, ed. Ryan Carey, 3-11. N.p.: n.p, 2015.

Malina, Bruce. The New Testament World: Insights from Cultural Anthropology. Louisville: Westminster John Knox, 2001.

McFee, Daniel E. "Values, Value Judgments." In Dictionary of Scripture and Ethics, ed. Joel B. Green, 803-805. Grand Rapids: Baker Academic, 2011.

Merk, Otto. "Ethics - NT Ethics." In The Encyclopedia of Christianity, vol. 2, ed. Erwin Fahlbusch et al. Grand Rapids: Eerdmans. Leiden: Brill, 2001.

Mühling, Markus. Systematische Theologie: Ethik. Eine christliche Theorie vorzuziehenden Handelns. Göttingen: Vandenhoeck \& Ruprecht, 2012.

Rai, Tage Shakti. "Moral Psychology is Relationship Regulation.” Ph.D. Dissertation, University of California, Los Angeles, 2012.

Rosling, Hans with Rosling, Ola and Rosling Rönnlund, Anna. Factfulness: Ten Reasons We're Wrong about the World - and Why Things are Better Than You Think. New York: Flatiron Books, 2018.

Schrage, Wolfgang. Ethik des Neuen Testaments. Berlin: Evangelische Verlagsanstalt, 1985.

Sheppard, Blair H. and Tuchinsky, Maria. "Interfirm Relationships: A Grammar of Pairs." In Research in Organizational Behavior 18, ed. Barry M. Staw and L. L. Cummings, 331-373. Greenwich: JAI Press, 1996. 
Simpson, Ain and Laham, Simon M. "Different Relational Models Underlie Prototypical Left and Right Positions on Social Issues." European Journal of Social Psychology 45, no. 2 (2015): 204-217.

Singer, Peter. The Life You Can Save: How to Play Your Part in Ending World Poverty. London: Picador, 2009.

The Most Good You Can Do: How Effective Altruism Is Changing Ideas about Living Ethically. New Haven: Yale University Press, 2015. and MacAskill, William. "Introduction." In The Effective Altruism Handbook, ed. Ryan Carey. N.p.: n.p, 2015.

Todd, Benjamin and the 80,000 Hours Team. 80,000 Hours: Find a Fulfilling Career That Does Good. Oxford: Centre for Effective Altruism, 2016.

Wydick, Bruce. Shrewd Samaritan: Faith, Economics, and the Road to Loving Our Global Neighbor. Nashville: Nelson, 2019. 
